\title{
POESIENS FIKTIONSLABILE "JEG" TEORETISKE OVERVEJELSER OVER DET LYRISKE JEGS FIKTIONSSTATUS
}

\section{THE FICTIVE-LABILE “I” OF POETRY | This article asks the question: what is the fictional} status of the l-enunciation in a lyric poem? When people read a lyric poem in the first person, they tend to automatically assume that the poet speaks in her own voice. But is it okay to think of this as the "default setting" of lyric poetry? In this paper, two congenial essays are broached and both of them are used to enhance the other's argument. The first essay is Susan Lanser's "The 'I' of the Beholder: Equivocal Attachments and the Limits of Structuralist Narratology". In this essay she deals with homodiegetic fiction, and she tries to conjecture under which circumstances readers are likely to attach an "I" in a piece of literature to the "I" of the empirical author. She proposes five criteria which make the reader prone to infer attachment, and as she finds them almost always to be present in lyric poetry, she concludes that it is primed for authorial attachment. This article, however, finds it problematic that she presupposes that lyric poetry is a constant genre. To remedy this, Ralph Rader's essay "The Dramatic Monologue and Related Lyric Forms" is introduced. It distinguishes between four types of lyric poems based on the affinity or distance between the poet and the speaker in the poem. Lanser's criteria are applied to each type of lyric poem. Rader, however, needs to incorporate reflections on how narrativity affects this poet-speaker relationship. Finally, the article presents a model which visualises and fuses the two theories, concluding that the "l" in lyric poetry is fictive-labile.

KEYWORDS | Lyric poetry, narrativity, fictionality, identity, reliability, pragmatism, rhetorical narratology

Erkendelsesinteressen i denne artikel kan opsummeres med spørgsmålet: hvilken fiktionsstatus har jeg-udsigelsen i et lyrisk digt? Når man læser et lyrisk digt med jeg-udsigelse, tænker mange per automatik, at digteren taler med egen stemme. Antagelsen har en stærk rod i romantikkens poetik. I sin indflydelsesrige bog The Mirror and the Lamp: Romantic Theory and the Critical Tradition skriver M.H. Abrams således, at størstedelen af lyriske digte består af "tanker og følelser ytret i første person, hvor den umiddelbart tilgængelige karakter, som man kan henføre disse

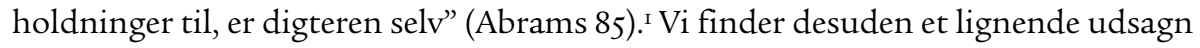
helt tilbage i bog tre i Platons Staten, hvor han siger, at dityramben består af digte-

I Alle engelsksprogede citater er til lejligheden oversat af forfatteren. 
rens ord alene (i modsætning til dramaet, der anvender direkte tale, og epikken, der blander direkte tale med digterens egne ord). ${ }^{2}$ Selvom man naturligvis kan debattere (som Genette f.eks. har gjort det, cf. litteraturlisten), i hvor høj grad dityramben kan gøres til eksponent for det lyriske digt, samt i hvor høj grad en antik forestilling om det lyriske digt kan sammenlignes med en romantisk, så vidner de to tekster om, at man i forskellige epoker har haft en forestilling om en overensstemmelse mellem et digts jeg-udsiger og digtets ophavsmand.

Når det er tilfældet, at man har gjort sig denne forestilling, er det nærliggende at spørge til dens årsag: hvilke formelle kriterier muliggør eller sandsynliggør den? I denne artikel er det ikke min hensigt at afsige endelig dom i denne sag, men måske nok at gøre indsigelser over for fastfrosne og unuancerede forestillinger. Konkret vil jeg introducere til og sammenligne to åndsbeslægtede artikler: Susan Lansers "The 'I' of the Beholder: Equivocal Attachments and the Limits of Structuralist Narratology” fra 2006 og Ralph Raders ”The Dramatic Monologue and Related Lyric Forms" fra 1976. Begge kritikere er vigtige figurer inden for fortælleteorien, og de to artikler bidrager på hver sin måde til lyrikforskningen ved at anvende metoder fra narratologien til at undersøge det lyriske jegs fiktionsstatus. Den forhåndenværende studie er altså teoretisk diskuterende, snarere end digtlæsende. Jeg vil fremhæve styrkerne og svaghederne ved hver af de to teoretiske modeller samt argumentere for, at en sammentænkning af de to teorier vil være til begges fordel. Lanser opstiller på pragmatisk vis fem kriterier, der, når de er til stede, vil anspore en læser til at antage, at jeg-udsigelsen er autentisk. Hun konkluderer, at de fem kriterier næsten altid imødekommes i det lyriske digt. Rader opstiller ikke kriterier, men forsøger i stedet at skelne mellem fire forskellige typer af lyriske digte ud fra afstanden/nærheden mellem digteren og jeg-udsigeren. Det er mit overordnede argument, at Lansers fem formelle kriterier på den ene side vil styrke Raders antagelser, som ellers godt kan virke mere postulerede end begrundede. Særligt mangler Raders teori at forholde sig til, hvad forskellige grader af narrativitet gør ved forholdet mellem digter-jeg og udsiger-jeg. På den anden side kan Lansers udsagn om lyrik virke en smule forsimplet, men det vil jeg mene, at Raders fokus på flere typer af lyriske digte vil kunne afhjælpe.

\section{Homodiegetisk litteraturs tvetydighed}

Lansers analyseobjekt er homodiegetisk litteratur - det være i prosa eller på vers. Hun interesserer sig for det paradoks, at vi på den ene side har lært ikke at sætte lighedstegn mellem forfatteren og jegfortælleren i en fiktiv tekst, men at vi på den anden side tit ikke kan lade være med at gøre just det. I heterodiegetisk litteratur

2 Platon, Staten, kapitel 3, s. I2r: ”Det er vist lykkedes mig at gøre dig klart hvad du ikke forstod før, at digte og historier for det første kan bestå udelukkende af "efterligning" som i komedie og tragedie, sådan som du nævnte; for det andet af digterens egne ord alene - det mest nærliggende eksempel er dithyramben - og endelig af en forening af begge dele, som i episk digtning og forskellige andre digtformer. Er du med?”. 
er der en række teknikker, der typisk bliver forbundet med fiktion, f.eks. fortællerens alvidenhed og fokaliseringsstrategier. Men fordi selvbiografi og homodiegetisk fiktion benytter sig af de samme lingvistiske markører, er det ikke muligt at afgøre jegets fiktionsstatus ved at citere fra en tekst. Hun tager Dorrit Cohn til indtægt for at sige, at selv med særligt tvetydige jeg-tekster må vi til syvende og sidst læse dem som enten referentielle eller som fiktive og ikke som begge dele på samme tid. Lanser er ikke enig heri. Hun hævder, at vi jævnligt oscillerer mellem referentielle og fiktive læsninger, på trods af at det anses som en kardinalsynd at sætte lighedstegn mellem en forfatter og en jeg-udsiger. Det er derimod vores tilgang til problematikken, der skal ændres; mere præcist skal vi lade konteksten supplere teksten samt lade en pragmatisk tilgang supplere den strukturalistiske (hvis begrænsninger hun påpeger, jf. hendes essays undertitel): ”Derfor vil jeg ikke spørge, om uautoriserede krydsninger finder sted, men under bvilke omstcendigheder det er sandsynligt, at de vil indtræffe" (Lanser 206). At disse krydsninger forekommer, er et faktum, og Lanser ønsker at undersøge, hvilke anvendte midler, der afstedkommer, at et udsagn fra et fiktivt jeg ikke kun opfattes som dettes udsagn, men også kan henføres til selve forfatteren.

Til det formål skelner hun mellem tekster, hun kalder for tilknyttede (på engelsk: attached), og tekster, hun kalder frakoblede (på engelsk: detached). I tilknyttede tekster antager læseren, at jeget i teksten stemmer overens med forfatterens virkelige jeg i anskuelser. Avisartikler, testamenter og forskningsmonografier er alle tilknyttede tekster. Det ses f.eks. af, at ingen kunne finde på at foreslå at tale om den implicitte forfatter til en forskningsmonografi. Brydes denne kontrakt, er det noget, der skaber genlyd. Hun nævner først og fremmest Sokal-affæren som eksempel på det (her fik en fysiker antaget en artikel i et fagfællebedømt tidsskrift af internationalt format for efterfølgende at hævde, at intet af det, han havde skrevet, gav mening). Eksempler på frakoblede tekster kunne f.eks. være nationalsange, reklamer eller fortalte vittigheder. Men det kan i lige så høj grad være konteksten som formen, der er afgørende for, om man er tilbøjelig til at udlede tilknytning eller frakobling. At genredistinktioner i sig selv kan være pragmatiske, viser hun, at Käte Hamburger har eksemplificeret med Novalis' Hellige Sange (Geistliche Lieder), der læses som lyrik, når vi møder dem i en digtsamling, men som hymne, når vi møder dem i en protestantisk hymne, hvor jeget i teksten refererer til den syngende menighed (ibid. 2IO). Når Lanser taler om tilknytning og frakobling, er hun altså ikke bleg for at sammenligne fiktive tekster med ikke-fiktive. Dvs. det er netop hendes pointe, at en pragmatisk tilgang gør det muligt at sammenligne tekster på tværs af fag- og skønlitteratur (og journalistik m.m.). Det skal dog siges, at når hun lancerer de fem tilknytningskriterier, som vi nu vil introducere, så er det primært med eksempler fra skønlitteratur. 


\section{Tilknytningskriterier}

Begreberne tilknytning og frakobling skaber en pragmatisk akse, der går på tværs af generiske grupperinger, og Lanser stiller i forhold til denne akse spørgsmålet: "Hvilke signaler i teksten vil lede os til at tage hvad der formelt set er en fiktiv stemme for at være forfatterens på trods af vores instruktioner om ikke at gøre sådan?” (ibid. 2II). Hun foreslår da fem formelle kriterier, der, når de er opfyldte, hver for sig foranlediger læseren til at antage tilknytning, og supplerer desuden, at kriterierne kan hjælpe til at forklare, hvorfor man konventionelt har betragtet det lyriske digt som det mest tilknyttede, dramaet som det mest frakoblede og fortællingen som den mest tvetydige genre blandt de tre storgenrer, som litteraturvidenskaben traditionelt har opereret med. Det første kriterium er singularitet, hvilket slet og ret betyder, at der kun skal være én stemme på tekstens højeste diegetiske niveau. Dette gør sig næsten altid gældende i lyrisk poesi, mens det modsatte næsten altid gør sig gældende i dramaet, hvor mange (karakterers) stemmer udfolder sig på det samme diegetiske niveau. Det andet kriterium er anonymitet; det defineres som fraværet af et egennavn til tekstens taler (medmindre navnet er identisk med forfatterens), hvilket er tilfældet i rigtig mange romaner og i næsten alle lyriske digte. Kriterium nummer tre er identitet, og hermed menes alle sociale ligheder mellem jeg-udsigeren og forfatteren. Identitetsindikationer kan være navn, køn, race, alder, biografisk baggrund, livsanskuelse og værdier eller beskæftigelse som forfatter. Lanser nævner, at selv hvis tekstens jeg bærer et andet navn end forfatterens, vil læseren udlede tilknytning, når forfatterens identitet stemmer overens med jegfortællerens identitet (hun nævner Charlotte Brontës Jane Eyre og Sylvia Plaths The Bell Jar som eksempler). Et åbenlyst problem ved dette kriterium, vil jeg hævde, er, at det forudsætter kendskab til forfatterens identitet, hvilket man ikke altid har. Det måske mest oplagte eksempel her er Shakespeare, hvor indsigten i hans liv (f.eks. i form af dagbøger, breve, omtale i andres dokumenter etc.) er yderst knap, og hvor man konstruerer versioner af den historiske person via hans værker og ikke omvendt. F.eks. er det ud fra en tilknytningshypotetisk læsning af nogle af sonetterne, at man konstruerer en biseksuel version af Shakespeare; i Shakespeares tilfælde vil jeg nok mene, at det som sonet-jeget siger i åbningen af sonet 53 om den unge mand, de første 126 sonetter adresserer - "What is your substance, whereof are you made, / That millions of strange shadows on you tend?" (Shakespeare 1940) - er sandt om de I54 sonetters egen jeg-udsiger (eller egne jeg-udsigere). Det fjerde kriterium er pålidelighed, og det betegner læserens forvisning (naturligvis efter grundige overvejelser og stor opmærksomhed over for teksten) om, at fortællerens værdier og anskuelser stemmer overens med forfatterens, og Lanser hævder, at pålidelighed er det eneste af kriterierne, hvis fravær aktivt umuliggør tilknytning: "Hvor pålidelighed ikke i sig selv determinerer tilknytning ... så er upålidelighed tilbøjelig til at forhindre tilknytning i at indtræffe" (Lanser 213). En jegfortællers u- og pålidelighed er et meget stort og omdiskuteret emne inden for fortælleteorien, og den diskussion vil jeg ikke gå ind i her. Blot vil jeg stille mig skeptisk over for 
Lansers kategoriske afvisning af tilknytning i tekster med upålidelige jegfortællere; eller måske snarere den uudtalte forudsætning, at upålidelighed ikke skulle kunne eksistere i forbindelse med virkelige personer. Selvfølgelig kan det det. Man kan f.eks. sagtens forestille sig en ikke-fiktiv dagbog eller et ikke-fiktivt brev, hvori en person gengiver eller fortolker på et hændelsesforløb på en stærkt subjektiv måde, en måde de færreste andre vidner i sagen ville erklære sig enig i, med andre ord: en upålidelig fortæller. ${ }^{3}$ Lanser foreslår to termer til det femte og sidste kriterium, nonnarrativitet eller atemporalitet.

"Dette kriterium mener jeg skal udmærke talehandlinger, der ikke gengiver karakterers eller begivenheders handlinger, ord eller adfærd, som de udfolder sig over tid. Jeg tror læsere er mere tilbøjelige til at antage tilknytning mellem fortællere og deres forfatter, når det fortællende "jeg" ikke rapporterer eller handler i begivenheder." (ibid.)

Hun opstiller i forlængelse heraf hypotesen, at de tvetydige genrer, der det ene øjeblik bærer præg af tilknytning, det næste øjeblik af frakobling, vil svinge mellem disse to tilstande i tæt forbindelse med tekstens grad af narrativitet. Det vil sige, at de atemporale eller nonnarrative talehandlinger i teksten vil anspore til tilknytning, selv når de optræder inden for et værk, der udgiver sig for at være fiktion.

Disse fem kriterier - singularitet, anonymitet, identitet, pålidelighed og atemporalitet/nonnarrativitet - fører hende tilbage til genreovervejelser. Hun citerer Brian McHale for at sige, at "antagelsen af selvbiografisk autenticitet, af identitet mellem digtets 'jeg' og digterens selv, er noget i retning af en 'default setting' for lyriske digte" (citeret i Lanser 2I4), og denne påstand af en "default setting” underbygges af de kriterier, hun lige har opstillet:

"Lyrisk poesi med dens konventionelle singularitet, dens almindelige anonymitet, dens næsten aksiomatiske pålidelighed, dens sandsynlige fremkaldelse af noget af forfatterens identitet og dens relativt lave grad af narrativitet gør den forhåndsinstrueret til tilknytning." (Lanser 2I3)

Hun spekulerer endda videre, at lyrisk poesi er så optaget af nonnarrative tanker, af følelser og af visioner, at begivenheder kan glide ubemærket forbi, hvis de ikke umiddelbart forekommer at være centrale. Det vil sige, at læseren i sådanne tilfælde vil tilknytte et lyrisk jeg til en forfatter, mens det narrative jeg ikke tilknyttes forfatteren, på trods af at det strengt taget er det samme jeg, der er tale om. Denne manøvre kan laves, fordi "digtets narrative apparat tjener nonnarrative formål” 
(ibid. 215).4 Det skal siges, at Lansers essay ikke arbejder sig frem mod specifikt at beskrive det lyriske digt. Hendes kommentarer herom falder drypvist, men de er ikke af den grund ufunderede i refleksion, hvilket min gengivelse af argumenterne forhåbentlig også viser. Hendes hovedærinde er at introducere begreberne tilknytning og frakobling og de fem kriterier i forhold til alle typer jeg-tekster, og mod slutningen af essayet retter hun sit fokus mod homodiegetisk fiktion (hvilket for hende betegner romaner fortalt i første person), fordi hun mener, den er den mest komplekse og tvetydige genre, hvad angår spørgsmålet om tilknytning og frakobling (den er "altid teknisk set frakoblet, men kan alligevel af og til uden videre tilknyttes", ibid. 2I4).

Selvom beskrivelsen af den lyriske genre altså ikke er hendes hovedærinde, og selvom jeg generelt er sympatisk indstillet over for hendes teori - jeg synes sådan set, den er rigtig god! - vil jeg alligevel tillade mig at sætte spørgsmålstegn ved hovedkonklusionen om den lyriske genre: at den ansporer til tilknytning. For der hersker med sådan et udsagn en uudsagt antagelse af, at lyrisk poesi er en lettilgængelig og fastforankret genre. Men den lyriske genre er notorisk svær at definere. Det er den delvis på grund af det historiske spænd fra - lad os sige Sapfo til Inger Christensen. Det ville være absurd at forestille sig, at den skulle være immun over for ændringer over tid, på tværs af kulturer etc. Tænk blot på, hvordan digter-opfattelsen ændrede sig under romantikken! Et andet problem med lyrik-som-fastforankret-og-homogen-genre-præmissen er - foruden de historiske ændringer - at der findes utrolig mange digttyper, der er meget forskellige i deres form og typiske indhold, som man har betragtet som værende lyriske. I en artikel med titlen "Who Reads Poetry?” nævner Virginia Jackson f.eks. følgende digttyper, der alle af nogle teoretikere betragtes som værende lyriske: "Sange, gåder, epigrammer, sonetter, epitafier, blazoner, lieder, elegier, "march'er", dialoger, vid [på engelsk: conceit], ballader, epistler, hymner, oder, ekloger og dramatiske monologer" (Jackson I83), og listen kan uden tvivl fortsættes.

Jeg skal ikke her gå nøjere ind i genredefinitionernes komplekse verden, hvor definitionen af den lyriske genre må siges at være særlig problematisk, men blot gå videre med Lansers idé om frakobling og tilknytning specifikt i forhold til det lyriske digt. Det er ikke helt urimeligt at hævde, at tilknytning mellem udsiger-jeg og digter er en slags "default setting", da det nok i mange tilfælde vil holde stik - ikke mindst at læsere antager, at det er således - men også at der rent faktisk er tale om et autentisk udsiger-jeg (i det omfang det nu kan bevises). Men alligevel mener jeg, det er misvisende at stoppe der. Jeg vil hævde, at tilknytning og frakobling kan være mindst lige så kompleks og tvetydig i lyrisk poesi som i homodiegetisk fiktion. På et specifikt niveau og i forhold til konkrete lyriske digte giver det mening at tale

4 Monique Morgan udgav i 2009 bogen Narrative Means, Lyric Ends. Temporality in the Nineteenth-Century British Long Poem, som også udforsker idéen, at de narrative elementer er midler til lyriske formål. Her er pointen dog ikke relateret til tilknytning og frakobling mellem udsiger-jeget og digteren; bogen sætter snarere fokus på det lyriske over for det narrative i forhold til kompositionsstrategier. 
om et autentisk jeg, men på et mere overordnet plan vil jeg hævde, at lyrisk poesi omspænder så mange forskellige typer digte, at det giver mere mening at snakke om et fiktionslabilt jeg, og her mener jeg, at Ralph Raders essay kan hjælpe Lanser, da han specifikt er ude på at skelne lyriske digte fra hinanden ud fra afstanden eller nærheden mellem forfatteren og digtets jeg-udsiger. 5 I resten af denne artikel vil jeg introducere Raders teori og anvende Lansers kriterier på de fire typer lyriske digte, han opererer med.

\section{Fire typer lyriske digte}

Ralph Raders essay "The Dramatic Monologue and Related Lyric Forms” begynder som en polemik mod nykritikkens, og navnlig Monroe og Beardsleys, dogmer om intentionelle og biografiske fejlslutninger, ifølge hvilke det ikke er tilladeligt at lave koblinger mellem digtets "taler" og digteren selv. Denne automatiske antagelse af frakobling er for Rader selv en fejlslutning, fordi Monroe og Beardsley ikke ser digtets forhold til dets digter som en iboende del af digtets objektive semantiske struktur, men som et udefrakommende forhold, vi som læsere pådutter digtet med baggrund i kilder, der ikke selv er i digtet. Som en ægte proponent for Chicagoskolen eller neo-aristotelikerne (hvor Booths begreb om den implicitte forfatter også stammer fra), mener Rader, at vi forstår digtene som ”objekter, hvis mening og relation til den virkelige verden sættes fast af den iboende digters [på engelsk: indwelling poet's] immanente intention" (Rader I32). Moderne poesi består ofte af et dramatiseret jeg, der handler i en konkret situation, og Rader mener, at figurerne i disse forskellige digte indgår i et specifikt forhold til deres forfatter. Han vil da adskille disse digte ud fra den måde, digteren forholder sig til figuren i digtet på.

Før han lancerer sit eget forslag, introducerer han to måder at gribe problemstillingen an på. Den første position er Robert Langbaums; han inddeler (dramatiske) lyriske digte i to grupper: dramatisk lyrik og dramatisk monolog. I dramatisk lyrik er jeget ligesom en rigtig person, der næsten falder sammen med digterens virkelige jeg, men jegets oplevelser og erfaringer i digtet er ubestemmelige, fordi digtets objekt ikke er i den samme verden som digterens. I den dramatiske monolog er digteren og jeget forskellige, men jeget er som en virkelig person, som vi betragter med en blanding af sympati og evaluering. Sympati er for Langbaum en måde at "vide på, som jeg kalder romantisk projicering, hvad tyskerne kalder Einfühlung, hvad psykologerne kalder empati" (Langbaum, preface). Den anden position tilhører Elder Olson. Hun ser jeget i begge typer digte som digterens artificielle skabning (og dermed som forskelligt fra digteren) i modsætning til Langbaum, der betragter jeget i begge typer som "virkelige" personer, der er uafhængige af digterens skaberevner. De to positioner trækker altså skarpe fronter op: ”Olsons syn på digtet som udelukkende en digter-determineret kunstnerisk konstruktion over for Langbaums

5 For en problematisering af nogle af Lansers tilknytningskriterier anvendt på det selvbiografiske digt se Kjerkegaard 2010. 
forestilling om det som et ubestemmeligt naturligt faktum” (Rader I34). Rader indtager en syntetiserende position: de har begge ret, og de tager begge fejl. Som indvending mod Langbaums position nævner han, at vi i den dramatiske monolog (med Robert Brownings "My Last Duchess" fra I842 som eksempel) er klar over digterens tilstedeværelse, før nogen analytisk refleksion overhovedet har fundet sted, nemlig via rimene som præger hertugens tale:

"Hvis vi spørger os selv, om vi forestiller os, at ordene i digtet udtales af Hertugen, vil vi naturligvis opdage, at det gør vi. Hvis vi så spørger, om vi hører rimene i digtet som en del af Hertugens tale, vil vi opdage, at det gør vi ikke. Dette lille men vægtige faktum antyder selv uden videre analyse, at digterens tilstedeværelse i digtet er et fundamentalt aspekt af dets form, ikke en viden vi henter uden for digtet, men noget, som er uadskilleligt fra vores oplevelse af det.” (Ibid. I33-4)

Med et mediumstransponerende tankeeksperiment viser han, at Olsons position heller ikke er helt korrekt. Hvis vi forestiller os de to digte i filmversioner, så vil hertugen i Brownings digt være en karakter, der filmes, mens han taler til den kommende hertugindes envoyé, hvorimod vi i Matthew Arnolds "Dover Beach" fra I867 (som repræsentant for dramatisk lyrik) vil filme det, som beskrives. Her vil kameraet fungere som jegets øjne, mens digtets ord vil være indtalte. Dette syn på karaktererne vil blive bekræftet i en anden test, mener Rader. Hvis vi forestiller os de to digte læst op, så vil man dramatisere hertugens stemme i "My Last Duchess" ved at ændre sin egen stemme, mens en oplæsning af "Dover Beach” vil vise, at jegets stemme er en ideel "forlængelse af læserens egen stemme, at han på en måde ytrer ordene, som var de hans egne, eller rettere på vegne af den dramatiske taler, som om læseren var blevet til denne taler” (ibid. I34). Rader konkluderer, at vi automatisk tænker, at hertugens jeg ikke svarer til digterens jeg, mens det modsatte er tilfældet i "Dover Beach”. På den ene side er digterens kunstneriske og dermed også kunstige - handling en synlig del af digtene, hvilket svarer til det, som en anden neo-aristoteliker, James Phelan, senere har kaldt for karakterernes syntetiske dimension. Men på den anden side virker karaktererne som "virkelige" og "uafhængige" væsner, hvilket Phelan betegner som karakterernes mimetiske dimension. Rader mener, at Langbaum mangler at indse vigtigheden af det syntetiske, mens Olson ikke har nok øje for det mimetiske.

Rader vil da komme med sit eget bud på en beskrivelse af disse digttyper. Han mener, at alt for mange digte er blevet betegnet som dramatiske monologer, og han mener desuden, at der er brug for to underinddelinger foruden dramatisk monolog og dramatisk lyrik; nemlig ekspressiv lyrik og maskelyrik. I det følgende vil jeg introducere disse fire digttyper samt afprøve Lansers tilknytningskriterier på dem med de digte, Rader anvender som repræsentanter for digttyperne, som eksempler. De fire digttyper skelnes ud fra den afstand eller nærhed, der hersker mellem jeg-udsigeren i digtet og den empiriske digter. Den type digte med størst afstand er den dramatiske monolog. For at opsummere og udbygge de karakteristika, vi 
nævnte i det foregående, kan man sige, at taleren altid kan lokaliseres i en fokuseret situation; man kan forestille sig et fotografi af denne situation med taleren, tilhøreren, omgivelserne etc. Digteren simulerer en persons handlinger, som om de var virkelige; vi forstår denne person, som vi forstår mennesker i den virkelige verden, idet vi udleder indre hensigter ud fra ydre handlinger og udsagn. Taleren kan være os overlegen eller underlegen i viden eller magt, hvilket medfører, at læseren kan indtage forskellige positioner over for denne: vi kan udvise seriøse forsøg på "forståelse", når taleren er overlegen, og "komisk nedladenhed", når taleren er os underlegen (ibid. 139). Men disse udledninger fra ydre handlinger til indre motiver gør naturligvis, at ting kan fortolkes forskelligt. Hvad angår spørgsmålet om, hvorfor hertugen fortæller sin selvudleverende historie til envoyéen, nøjes Langbaum f.eks. med at konstatere, at mange udsagn i den dramatiske monolog er umotiverede, at der er en række udsagn, der ikke har en oplagt adressat (altså inden for fiktionen; den virkelige adressat er læseren). Men her vil Rader snarere mene, at hertugen røber sig selv med overlagt kalkulation: nemlig for at advare den kommende hertuginde gennem tilhøreren (hvad narratologer på engelsk ville kalde the narratee; den der tales til inden for fiktionen; denne ytrer i øvrigt ikke et ord) om sin utilfredshed med sin sidste hertugindes overdrevne begejstring for alt i øst og vest, noget som han ikke ville nedlade sig til at påpege over for hende.

Men hovedpointen er altså, at "personen og objekterne ikke er symbolske, men bogstavelige, naturlige, men ikke faktiske" (ibid. I5I). Før vi går over til maskelyrikken, kan vi nævne, at Rader selv har det med at tegne for sort-hvide scenarier op; her kan det måske være på sin plads at nævne den sidste af de tre dimensioner, som, Phelan mener, udgør en karakter: nemlig den tematiske (de to andre var som sagt den syntetiske og den mimetiske). For pointen her er, at en karakter altid vil indeholde et element af alle tre, men at én af dimensionerne selvfølgelig sagtens kan være fremhævet på de andres bekostning. Således kan man altså godt forestille sig, at personerne eller objekterne i en dramatisk monolog også kan være symbolske (eller tematiske), selvom størstedelen af fokusset er lagt på deres mimetiske funktion! Hvis vi prøver at koble Lansers kriterier på ”My Last Duchess”, får vi styrket Raders dom om frakobling i digtet. Der er ikke anonymitet, da det er hertugen, der taler (hans titel fungerer vel som en slags navn); der er ingen identitetsmæssige overensstemmelser mellem hertugen og Browning på nogen måde (digtet er baseret på begivenheder i Alfonso II’s liv; han var hertug i Ferrara i Italien, og hans første hertuginde døde i I56I efter tre års ægteskab); hertugen er et skoleeksempel på en upålidelig fortæller; og digtet er relativt narrativt og temporalt. Godt nok er der kun én udsiger på det højeste diegetiske niveau, men digtet har den dramatiske karakter: det hele er direkte tale, og envoyéen kunne i princippet sagtens bryde ind og sige noget, så singulariteten er bestemt også tvivlsom.

Den næste type digt er maskelyrikken. Den adskiller sig fra den dramatiske monolog ved, at taleren "ikke er en simuleret naturlig person i kontrast til digteren, men en artificiel person, som er projiceret af digteren, en maske igennem hvilken han taler” (ibid. I40). På den måde kan digteren give udtryk for en oprigtig, 
autentisk følelse, men på samme tid dissocierer han sig fra den via fiktionen. Det er mærkbart, at disse digte ofte antyder en fiktiv eller mytologisk status (T.S. Eliots "The Love Song of J. Alfred Prufrock" ville være et eksempel, ligesom Tennysons "Ulysses" er det). Rader tænker det i forlængelse af T.S. Eliots teorier og digte og særligt forestillingen om et objektivt korrelat, hvor digteren skaber et artificielt ydre korrelat af en indre, sand følelse i ham selv. Sammenlignet med kulissen i den dramatiske monolog er man i maskelyrikken ikke klar over præcis, hvor taleren er i rummet, ej heller hvordan denne bevæger sig i det. I en filmversion af maskelyrikken ville man kunne forestille sig talerens stemme akkompagneret af "en montage af utydelige og hurtigt skiftende scener, hvis mangel på konkretion ville underbygge den ekspressive artificialitet; scenen ville ikke være realistisk, men snarere surrealistisk" (ibid. I4I). Hvis vi igen forsøger at koble Lansers tilknytningskriterier på maskelyrikken med Tennysons "Ulysses” (skrevet i I833, udgivet i I842) som eksempel, så er der tale om singularitet, og tilhørerne (Odysseus' mandskab) er endnu mere tavse end i den dramatiske monolog. Der er ikke anonymitet, da det er Odysseus, der taler. Jeg finder ikke umiddelbart nogen grund til at mistænke taleren for at være upålidelig. Atemporalitet eller nonnarrativitet er lidt mere tvetydigt. Odysseus taler angiveligt til sine sømænd og anmoder dem om at sejle ud med ham endnu en gang ("Some work of noble note, may yet be done", Tennyson I2I4). Men det narrative er sparsomt og giver blot anledning til hans tale. Maskelyrikkens fiktive form forlener digteren med en mulighed for at udtrykke følelser, tanker eller erfaringer, som han måske ikke ville ytre i eget navn (Phelan $\&$ Richter 78). I "Ulysses" har kritikere f.eks. tolket, at Tennyson via masken mediterer over selvmordsimpulser, før han beslutter sig for at sejle ud igen. På den måde bliver identitetskriteriet tvetydigt. Men vi kan altså konkludere, at vi med maskelyrikken har bevæget os et godt stykke længere mod tilknytning i forhold til den dramatiske monolog, som er meget frakoblet.

Den næste digttype er den dramatiske lyrik, som også blev vendt i diskussionen mellem Langbaum og Olson. Her deltager vi i talerens mentale forestilling og ser tingene gennem dennes øjne. Vi erfarer digtets erkendelse indefra og ud, hvilket er modsat i forhold til den dramatiske monolog, hvor man konstruerer det indre gennem det ydre (en karakters direkte tale). Digteren gengiver ifølge Rader typisk en rigtig hændelse og tankerne og følelserne, der er forbundet hermed. Det reflekteres også i titlerne, der ofte er opkaldt efter objekter (og ikke f.eks. mytologiske eller fiktive figurer som i maskelyrikken): "Disse digte er karakteristisk opkaldt efter objekter - en kirkegård, "havudsigt” [mine anførselstegn; på engelsk: seascape], høg der er oplevede, ikke skabte, og som ligger til grund for den erfaring, digtet giver os" (Rader I44). Der anvendes altså et naturligt objekt, som kan findes i den virkelige verden, men som digteren ser noget særligt symbolsk i. I eksemplet med Matthew Arnolds ”Dover Beach” fra I867 er det så stranden ved Dover, der inspirerer til den lyriske refleksion. I den dramatiske lyrik tager digteren altså ifølge Rader en signifikant hændelse fra den virkelige verden og simulerer den som værende præsentisk for den dramatiske lyriske taler. Den har sin oprindelse i hukommelsen, men er i 
sin rekonstruktion frigjort fra hukommelsen: "jeg tænker på disse digte, som om de var blevet skabt af digteren til at svare mimetisk i et her og nu til det indtryk af en virkelig fortidig oplevelse, det efterlod i hans erindring. Oplevelsen skabes ikke, men genskabes, eller mere præcist, dens betydning gen-skabes” (ibid. I43). Digteren og taleren er altså to enheder, men de konvergerer næsten fuldstændigt. En forskel er dog, at digteren fra starten ved det, som aktøren først opdager til sidst. Prøver vi igen Lansers kriterier af på digtet, ser vi, at der er stærkere tilknytning mellem digter og jeg end i de to foregående digttyper. Der er både singularitet og anonymitet. Digtet er atemporalt og nonnarrativt (mere end "Ulysses"). Der er ikke nogen markører, der ansporer til upålidelighedshypoteser. Identitet er igen vanskeligt at sige noget endegyldigt om. Alder og køn angives ikke. Hvis man kender noget til Matthew Arnolds livsanskuelse, vil man spore ligheder, men her er spørgsmålet igen, om vi konstruerer hans livssyn ud fra digtet, eller om vi tager det udefra og anbringer - for derefter bekvemt at finde - det i digtet. Og om der overhovedet er forskel. Lanser og Rader vil nok ikke mene, at der er det.

Den sidste digttype kalder Rader for ekspressiv lyrik, og her er William Wordsworths "Tintern Abbey” fra I798 eksemplet. Mange af de samme ting gør sig gældende her som i dramatisk lyrik, men der er ikke en sammenblanding af digter og taler. Der er slet og ret digteren. Digtet representerer ikke en dramatisk persons tanker; det presenterer digterens tanker direkte. Oplevelsen opnås i øjeblikket. Der er ikke nogen kunstnerisk gen-skabelse som i dramatisk lyrik:

"Det er netop, som om digteren havde begyndt digtet ekstemporalt, som et forsøg på at udtrykke kraftige følelsers spontane overløb [indirekte Wordsworth-citat fra forordet til Lyrical Ballads], som landskabet vækkede i ham, idet han bevæger sig hen mod en ekspressiv konklusion, hvis form han opfatter intuitivt fra begyndelsen, men uden klart at forudse den." (ibid. I44-5)

Digteren taler i egen person, og digtet er udsprunget af en virkelig oplevelse, som digteren forsøger at kommunikere. Digteren opdager i processen ordene og formen, der passer til at beskrive hans indre. Rader sammenligner det med et brev, man skriver i flere seancer; det komponeres "i sekvenser som en dynamisk respons til omstændighederne" (ibid. I50). Desuden har vi mere biografisk viden om digtet, end vi har om "Dover Beach". Det kendes som "Tintern Abbey", men dets egentlige titel er "Lines Composed a Few Miles above Tintern Abbey, on Revisiting the Banks of the Wye during a Tour, July I3, I798", så det er endda dateret. Og det "du”, der skrives til, omtales "My dear, dear Sister" i vers I2I. Rader mener, at vi skal kalde jeget for Wordsworth og den tiltalte for Dorothy Wordsworth; vi kan ikke på samme måde kalde den, der tales til i "Dover Beach”, for fru Arnold, selvom det er meget sandsynligt, at det er hende, der tales til. Rader mener endda, at det er "svært overhovedet at tænke på 'Tintern Abbey' som værende kunstfærdig” (ibid. I45). Jeg vil give Rader ret i, at digtet er mere eksplicit selvbiografisk end Matthew Arnolds, men det er svært ikke at se det som kunstfærdigt. Der er både jambisk 
pentameter i versene samt en hyppig metaforbrug. Man må nok i det hele taget sige, at det kun kan foregive at være en prosentation (og ikke en re-prosentation).

Med de fire digte er det altså muligt at skabe et kontinuum ud fra afstanden eller nærheden mellem jeg-udsigeren og digteren. De to er decideret frakoblede i den dramatiske monolog, mens de er sammenfaldende i ekspressiv lyrik; maskelyrik og dramatisk lyrik har varierende grader af interferens. Kobler vi Lansers kriterier på, kan vi tegne følgende figur, der viser, hvordan digterens forhold til jeg-udsigeren er i de respektive eksempler på de respektive digttyper, samt hvilke af Lansers kriterier der er opfyldt i hvilke digte:
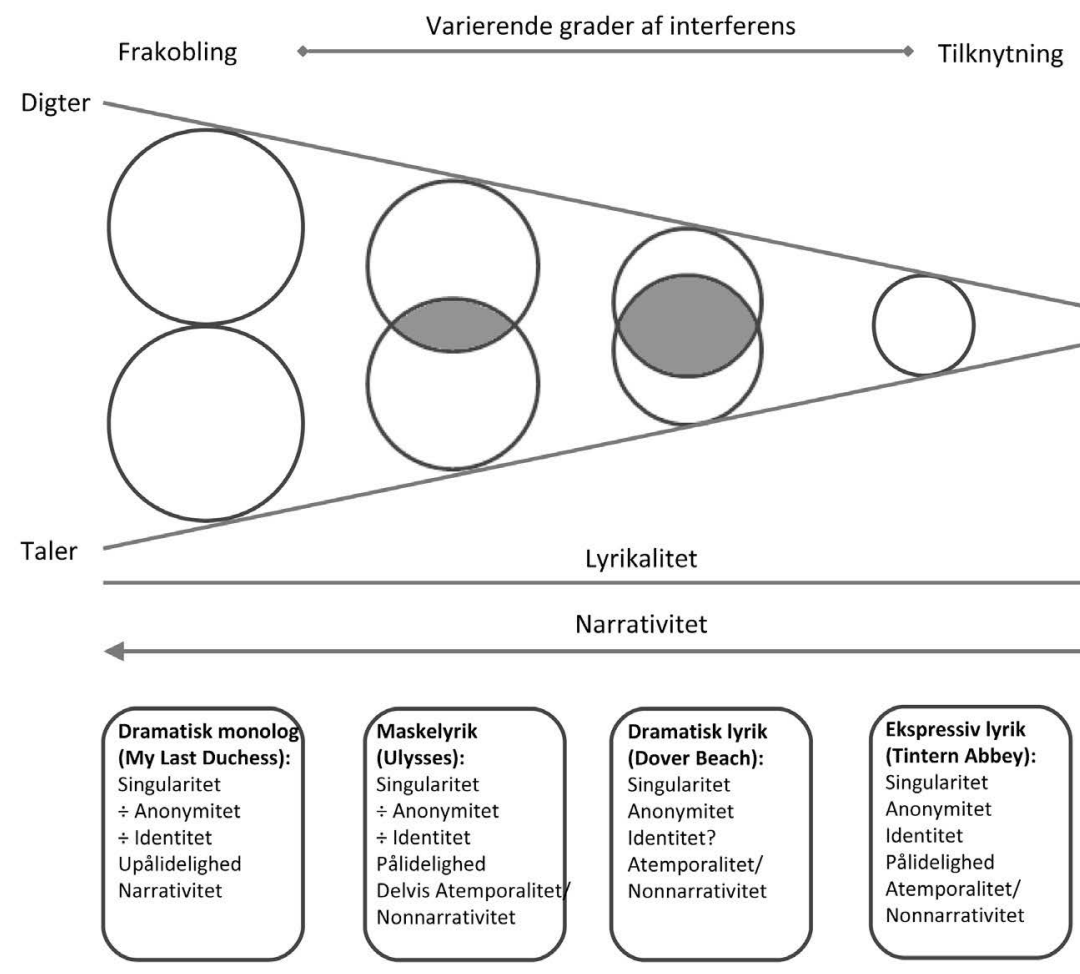

\section{Konklusion}

Mod slutningen af sit essay konkluderer Rader:

”Jeg mener, at de formelle forklaringer jeg har udviklet ud fra [disse begreber] er tilstrækkelige til at indikere, at alle disse digte [dvs. dem, der har gået under betegnelsen dramatisk monolog] er mere varierede i basal struktur, og at deres underklasser er mere særskilte, end den gængse doktrin generelt har givet plads til.” (Ibid. I5I) 
Lanser kunne som sagt godt have været mere åben over for disse forskellige typer af lyriske digte. Hvis hun prøvede kriterierne af på konkrete digte, ville hun hurtigt opdage, at poesiens jeg er mere fiktionslabilt end som så. Omvendt mener jeg, at Lansers formelle kriterier gavner Rader enormt meget. Deres tilgange har mange ligheder. F.eks. kigger de begge på paratekstens betydning; derudover kan Raders tilgang med de medietransponerende tankeeksperimenter ("hvis digtet var en film", "når digtet læses op", "hvis digtet var et fotografi", "hvis det var et brev, skrevet i flere seancer" etc.) med fordel applicere Lansers pragmatiske, men mere formelle kriterier til sin model. $\mathrm{Nu}$ "kritiserede" vi tidligere Lanser for at komme med generelle udsagn om det lyriske digt uden at have øje for de mange forskelle, der også er på lyriske digte, men med Rader forholder det sig omvendt. Han mener, at alle de fire digttyper er lyriske digte, og det på trods af, at den dramatiske monolog kan være temmelig narrativ; så især det at tænke Lansers kriterium om nonnarrativitet ind er noget, der vil forbedre hans model. Hvilken betydning har det narratives tilstedeværelse for digtet? Kigger man på de fire digte, Rader gør til repræsentanter på sit kontinuum, kan man f.eks. iagttage, at jo mere narrativt digtet er, desto mindre lyrisk er det og vice versa. På den måde siger de to teorier altså ikke kun noget om fiktionslabilitet i poesien, men også noget om forholdet mellem lyrik og fortælling: nemlig I) at de er to modsatrettede modi og 2) at de meget ofte sameksisterer i komplekse hybridformer.

I denne artikel har eksemplerne for modellen været Raders egne, som jeg så har anvendt Lansers kriterier på. Disse digte er fra begyndelsen af I8oo-tallet og ca. I20 år frem, men det gør ikke hans teori mindre aktuel, for der skrives i dag stadig masser af poesi med rod i romantikkens poetik. Raders eksempler viser, at det nittende århundredes digtning er præget af fiktionslabilitet, og spørgsmålet om fiktionslabilitet trænger sig bestemt ikke mindre på i dag. Som jeg skrev i introduktionen, er ærindet her at introducere en teori, så det ligger hinsides denne artikels begrænsninger at give en grundig historisk redegørelse. Jeg vil imidlertid opfordre til, at man afprøver I) Lansers fem kriterier, 2) Raders medietransponerende tankeeksperimenter og 3) Raders fire digttyper, som han definerer dem, på digte med jeg-udsigelse fra før I8oo-tallet samt fra det tyvende århundrede og frem til i dag. Ved punkt et og to vil jeg desuden opfordre til, at man afprøver kriterierne og tankeeksperimenterne på hele digte men også på forskellige momenter i det samme digt for at se, hvordan det påvirker fiktionslabiliteten. En sådan historisering tror jeg vil kunne bidrage til en bedre forståelse af udsigelsens fiktionsstatus i digte fra forskellige perioder, ligesom det diakrone perspektiv evt. vil kunne modificere den teoretiske model. Lanser har en forestilling om, at jegromaner er "den mest tvetydige af de tvetydige genrer" (Lanser 2I4), men spørgsmålet er, om ikke poesien - også den lyriske poesi, det være fra det nittende århundrede eller i dag - kan være lige så tvetydig? I hvert fald vil jeg plædere for, at man bør "de-defaulte" standartantagelser af arten: "I lyrik er det altid et autentisk jeg, der taler." 


\section{LITTERATURLISTE}

Abrams, M.H. The Mirror and the Lamp: Romantic Theory and the Critical Tradition. New York: Oxford University Press, I97I.

Arnold, Matthew. "Dover Beach”. The Norton Anthology of English Litterature. Red. M.H. Abrams. New York: W.W. Norton \& Company, 2000, I492-I493.

Browning, Robert. "My Last Duchess". The Norton Anthology of English Litterature. Red. M.H. Abrams. New York: W.W. Norton \& Company, 2000, I352-I353.

Genette, Gérard. The Architext. An Introduction. USA: University of California Press, 1992 (I979). Jackson, Virginia. ”Who Reads Poetry?”. PMLA I23.I (2008): I8I-I88.

Kjerkegaard, Stefan. "Genreopbrud I oo'ernes danske poesi. Det selvbiografiske digt”. Passage 63 (20IO): IO9-I27.

Langbaum, Robert. The Poetry of Experience. New York: W.W. Norton \& Company, I957.

Lanser, Susan. "The "I" of the Beholder: Equivocal Attachments and the Limits of Structuralist Narratology". A Companion to Narrative Theory. Red. James Phelan \& Peter Rabinowitz. Malden, MA: Blackwell Publishing, 2008, 206-220.

Morgan, Monique. Narrative Means, Lyric Ends. Temporality in the Nineteenth-Century British Long Poem. Columbus: Ohio State University Press, 2009.

Phelan, James. Living to Tell about It. A Rhetoric and Ethics of Character Narration. Ithaca: Cornell University Press, 2005.

Phelan, James \& David Richter. "The Literary Theoretical contribution of Ralph Rader". Narrative I8.I (20IO): 73-9I.

Platon. Staten. Viborg: Museum Tusculanums Forlag, 2007.

Rader, Ralph. ”The Dramatic Monologue and Related Lyric Forms”. Critical Inquiry 3.I (I976): I3I-I5I. Shakespeare, William. The Norton Shakespeare. New York: W.W. Norton \& Company, Inc., 1997.

Tennyson, Alfred Lord. "Ulysses”. The Norton Anthology of English Litterature. Red. M.H. Abrams. New York: W.W. Norton \& Company, 2000, I2I3-I2I5.

Wordsworth, William. "Tintern Abbey”. The Norton Anthology of English Litterature. Red. M.H. Abrams. New York: W.W. Norton \& Company, 2000, 235-238. 